\title{
Adult Foster Home
}

National Cancer Institute

\section{Source}

National Cancer Institute. Adult Foster Home. NCI Thesaurus. Code C154424.

A private home or other facility that provides care to persons of adult age in a home-like environment. 